Artigos/Articles

\title{
A critical, decolonial glance at language teacher education in Brazil: on being prepared to teach
}

Um olhar crítico decolonial na formação de professoras/es de línguas no Brasil: sobre estar preparada/o para ensinar

\author{
Mariana R. Mastrella-de-Andrade ${ }^{1}$ \\ Rosane Rocha Pessoa ${ }^{2}$
}

\section{ABSTRACT}

The decolonial accounts made by a student teacher motivated us to problematize discourses about the "unpreparedness to teach languages at schools", recurrent in the area of language teacher education in Brazil, and confront them with accounts of other student teachers and of applied linguistics, poststructuralist and decolonial scholars. In this interpretive study, discussions on the themes language, the subject and teaching, coming from the empirical material, led us to a perspective of teacher education as an "impossible but necessary project" (LOPES; BORGES, 2015) and to the need to educate language teachers "to talk" (SKLIAR, 2006), in view of the great complexity of teaching contexts.

Key-words: decolonial teacher education; language; the subject; teaching.

1. Universidade de Brasília - UnB. Brasília - Brasil. https://orcid.org/0000-0002-05390293. E-mail: marianamastrella@gmail.com.

2. Universidade Federal de Goiás - UFG. Goiás - Brasil. https://orcid.org/0000-00020538-2891. E-mail: pessoarosane@gmail.com. 


\section{RESUMO}

Relatos decoloniais de um licenciando nos motivaram a problematizar discursos sobre o "despreparo para ensinar línguas na escola", recorrentes na área de formação docente no Brasil, e a cotejá-los com os relatos de outras/os licenciandas/os e de estudiosas/os da linguística aplicada, do pós-estruturalismo e do pensamento decolonial. Neste estudo interpretativista, as discussões dos temas língua, sujeito $e$ ensino, advindos do material empírico, nos direcionaram a uma perspectiva de formação como um "projeto impossivel, porém necessário" (LOPES; BORGES, 2015), e à necessidade de formar professoras/es de línguas para "conversar" (SKLIAR, 2006), haja vista a grande complexidade dos contextos de atuação docente.

Palavras-chave: formação docente decolonial; língua; sujeito; ensino.

\section{The core issue of our discussion}

It was the last class of the academic term and the student teachers were evaluating the English Practicum Course after fulfilling their 60hour mandatory teaching practice in public schools around Brasília, capital city of Brazil. Two questions were on the board: how would you evaluate your teaching experience this semester? And how do you feel as you are about to graduate as an English teacher? As the discussions proceeded, heated and stormy at times, one word resounded in our minds: "unpreparedness". Student teachers about to graduate narrated their learning at the university as lacking substance in preparing them to face teaching positions at public schools. They regarded their preparation as too shallow, their confidence to teach English as too weak, and their desire to take over a teaching position at a public school as almost non-existent.

Without much surprise, we found out, while sharing experiences such as the vignette above, that such discourses have been more than common among language teacher education (Letras) students in Brazilian universities. Our experiences as teacher educators have shown that English teachers are constantly complaining about not being able or feeling confident to successfully teach the language in public schools. 
The feeling of "unpreparedness" seems to be recurrent in English teacher education institutions around the country, as we can see in different works (ASSIS-PETERSON; SILVA, 2011; BORELLI, 2018; CELANI, 2003; KADER; RICHTER, 2012; PESSOA; ANDRADE; FERREIRA, 2017). In this sense, we have been intrigued enough to take a critical glance at the meanings that have been attributed to "preparedness" or "competence." More than that, we have been willing to discuss what "unpreparedness" means and how we can look beyond it through critical, decolonial lenses.

Celani (2003:20) affirms that her long experience in the area of English teacher education, both pre and in-service, shows that English teachers are not "well-equipped to perform their educational task." Assis-Peterson and Silva (2011) critically discuss the trajectory of Liana, an English teacher in her first years of teaching. They say that she graduated in English Language Teaching (Letras: Inglês) with a feeling that the course did not

help her face the difficulties she came across within the public school context.

Disappointed, feeling useless, and not being able to conform to the students' and the school culture, she ended up giving up the dream of being a teacher. (ASSIS-PETERSON; SILVA, 2011:364).

Kader and Richter (2012:9) present English teachers' narratives reporting a feeling of unpreparedness to face teaching in schools; the authors discuss that the four-year teacher education courses are not enough to fulfil the goal of preparing teachers. In Pessoa, Andrade and Ferreira (2017), six out of the seven research teacher participants declared their dissatisfaction with their undergraduate English teacher education course. According to them, their course had proved frankly insufficient, but they felt so unprepared that they avoided identifying themselves as English teachers in the research. Besides, as they had a degree in both English and Portuguese Teacher Education, three of them opted to teach Portuguese and took on English lessons only to complete their class load.

3. This and other experts originally written in Portuguese have been translated into English by the authors of this article. 
This discussion over the so-called "lack of preparation" of many newly qualified English teachers refers us to the concept of competence (or competences) that theorizations on language teacher education usually consider. Scholars such as Perrenoud (1999), whose work supports many theorizations on teacher education from center-based countries, define teaching competence, broadly speaking, as knowledge, strategies and attitudes that language teachers have to acquire and mobilize in order to teach well in their classrooms. By looking quickly at such a broad concept, one could then question: should teachers who feel "unprepared," as the cases narrated above, be categorized as not possessing the necessary competences to do their teaching and move forward in the profession? It seems to us that terms such as "competent" and "prepared" evoke modern notions of closed, fixed, and once-and-for-all-defined states teachers are expected to achieve in order to say they can teach well. Biesta (2012a) also finds it worrying to have the term in reference to teacher education. He argues about the need and possibility to "think differently about education and about what teachers should be able to do" (BIESTA, 2012a:10, emphasis in original), explaining that

the idea of competence is beginning to monopolise the discourse about teaching and teacher education. It is, therefore, first of all the convergence towards one particular way of thinking and talking about teaching and teacher education that we should be worried about. After all, if there is no alternative discourse, if a particular idea is simply seen as 'common sense,' then there is a risk that it stops people from thinking at all. (BIESTA, 2012a:9).

Looking critically at all this, we consider, as Kumaravadivelu (2014:12) adverts, that "the construction and imposition of terminology reinforce and instil inferiority complex in the minds of the subaltern." The author claims that it is through center-based knowledges that marginality is managed and maintained, which calls for changing "not only the terms of the conversation [but also] changing the terms of the conduct of knowledge production" (KUMARAVADIVELU, 2012:16). Therefore, we question the use of terms such as "prepared" and "competent/competence" when they refer to teachers' readiness to face classroom challenges, underscoring the need to re-signify them towards more relational, contextual, and always-incomplete notions of teacher education (LOPES; BORGES, 2015; SKLIAR, 2006). 
Although most narratives of the student teachers in our English Practicum courses tended to entitle their experiences as insufficient to prepare them for the professional field, as we showed above, one narrative pointed out striking differences. Luciano Ricardo, one of the pre-service teachers, highlighted that the university did prepare him to teach in public schools:

the teacher education course prepared me [...] it's not that it filled me up, I'm not ready for the rest of my life, even because things change, places change, people change... [...] I do not know what I'm going to face, but I have courage, you know? ${ }^{4}$

His account led us to wonder: why was it that he reported to feel prepared, differently from the others? How come was he so more open to accept the complexity surrounding language classrooms in public schools? His words sounded like defiance to us: he was challenging the idea that teacher education could be done in definite, closed and complete models and that preparation would entail pre-fixed conceptions of subjects. He also defied the idea that rational information on how to manage classrooms, use textbooks, talk to students and parents, respond to school authorities and prevent difficulties in order to successfully teach, relevant as it may be, might ever be enough and complete, given the complexity of identities and social contexts language teaching encompasses.

What stroke to our minds, then, was that we needed to understand his defying attitude and take it further: how can we decolonize English teaching in Brazil in reference to teacher education processes? How can we educate teachers to feel more prepared and open to teach, and less dependent on center-based rational models of language teaching, which may scarcely apply to our realities, as Kumaravadivelu (2012:18-19) points out? What follows here, then, is our attempt to problematize the meanings constructed around the idea of "(un)preparedness" in language teacher education in Brazil, focusing on three important

4. Student teachers participating in this research (namely Donny and Luciano Ricardo) and $\mathrm{J}$, a teacher in her first year of teaching, signed a consent form in order to allow their discussions (in an English Practicum group) and individual interviews to be recorded and used for teacher education research. 
aspects brought up in Luciano Ricardo's accounts: teaching, the subject (identity) and language.

Our discussion is grounded on accounts by two male student teachers and one female teacher in her first year of teaching. The three of them studied at the Universidade de Brasilia $(U n B)$, their fictitious names are Luciano Ricardo, Donny and J. This study is interpretative, since we were involved in the process of interpretation and attribution of meaning to the events analyzed. According to Schwandt (2006), in interpretative research it is the human subject itself that constructs the knowledge of reality concerning different cultures in our societies, so there is no single or objective truth that is the answer to research inquiries. To him, it is the very interpretations of the researchers and the participants that bring into existence the theorizations built from what is investigated.

Along the text we turn to the conception of decoloniality, understood here as the undoing, disobeying, and delinking from the colonial matrix of power (or simply modernity/coloniality), which started to be constituted in the sixteenth century and since then has been reproduced in the hierarchies which haunt all aspects of social life, such as race, economy, politics, nationality, gender, sexuality, language, religion etc., in both micro and macro levels. In a way, this article is a struggle "from and within modernity/coloniality's borders and cracks to build a radically distinct world" (WALSH; MIGNOLO, 2018:5).

\section{Teachers' views on teaching and their influence on encounters with the school}

Considering the pre- and in-service teachers we had a chance to meet and talk to for this research, J's account on her first day as a teacher in a public school draws our attention to the meanings attributed to teaching. Although not directly addressed by her, teaching seems to be constructed in her report by means of a method and a textbook. Underlying these two elements is, as she puts it, the legitimacy of private institutions in Brazil as the places where teaching really happens: 
In private schools you are prepared, you know the school, you know the method, you know the levels, you have all preparation support to start. [On my first day as a public school English teacher] I decided to start with a revision because I didn't have any idea of the content, I didn't have any idea of the content the students had already seen, I didn't have any idea of anything, so... the thing that I came up with was... I said: 'I'll pull up something to at least give them a revision' and it was about the verb be. That's the regret I have these days, of having started that way, but on that day, at that moment of such pressure, when I didn't know how to handle things, that was what I came up with. And I started and taught that class all over the verb be. There wasn't even a textbook [...].

We find it relevant to notice in J's story how she mentions "private schools" as places where teaching works out well. Although narrating her first day in a public school, she first refers to how efficient teaching is in private institutions. In her account, they prepare their teachers to know the school, the method, the levels, and (we infer) the like. In public schools, however, things are supposedly different, which leads us to imagine that teaching, whatever it is, would not happen well there. Ideas like that are part of what Sousa (2009:84) calls the "demonization of the state" and the "idealisation of the market", that is, the market (to which private schools belong) is taken as "the kingdom of virtue" (SOUSA, 2009:84), the place where things are organized and people know exactly what to do and what to produce, since results are expected and checked out on and things cannot go wrong so that profits are granted. It is the place where businesses and customers' needs are, one way or another, satisfactorily met, for, again, profits must be guaranteed. In this sense, the public school in Brazil, run by the state and inhabited by lower-class students, does not matter so much to be put to work well. The state then appears as an incapable, inefficient manager, which should eventually be ousted from its position so that the market will rule education. Ideological as this is, according to Sousa (2009:82), the liberal thesis of efficacy speaks loudly in Brazil and in many other countries in the world. As he points out, however, we should not forget that the market only knows how to teach those who come to school "ready to be taught," that is, those who have had a family who cares for their security and values education, who are acquainted with school-like discipline, who are motivated to learn, have concentration skills and access to books. 
We believe the legitimacy of private schools as the places where teaching is successful, as considered above, pave the way on which $\mathrm{J}$ builds notions of teaching in relation to two elements, as we said before: method and textbooks. As for the first one, she said: "in private schools you are prepared, you know the school, you know the method." In other words, it means you know exactly what to do in private schools. Having a method means not only knowing what to do, but also how to handle things and what results to expect: the method here seems to be the way to accomplish things or, even more, ways to be in control (in opposition to, as J said, not knowing "how to handle things").

We agree with Kumaravadivelu (2014:8) in that "method functions as an operating principle shaping all other aspects of language education: curriculum, materials, testing, and training." That may be why we, teachers, miss grasping a method: it seems to take away the fear of being out of control. However, as Kumaravadivelu (2014:18) foregrounds,

since language learning and teaching needs, wants, and situations are unpredictably numerous, no idealized method can visualize all the variables in advance in order to provide situation-specific suggestions that practicing teachers need to tackle the challenges they confront in the practice of their everyday teaching.

How then has teacher education been preparing teachers to see the role of a method? Has teacher education in Brazil reinforced that one or another method holds the key to the teaching problems we face in public school classrooms? As we can see in J's account, having a method would mean knowing what to do in class in order to teach a language. Teaching, then, tends to come down to pre-given ways of transmitting knowledge rather than to a relational process in which subjects "talk" (SKLIAR, 2006:32) and find out ways to discover, practice, choose, use, learn etc., languages. Important as well is that the need and claim for $a$ method in order to put things in control derives from an idea of teaching as universal, that is, that every subject, from every community, learns the same way and, therefore, such a method is suitable for teaching any group of students. This is, in our view, a colonial way to see education, since almost all methods are based on "native speakerism" (KUMARAVADIVELU, 2014:8), that is, a notion 
that the "native speaker," whoever he/she is, is the model par excellence of language production. Also, it is colonial in the sense that learners are textually and rationally known beforehand. This means dismissing the need of knowing the students, their desires, needs, and realities in order to teach them; it means adopting a homogeneous, know-it-all epistemology on language teaching and learning. Lopes (2013:954) argues against it:

The research on foreign language teaching-learning and acquisition is still based, to some extent, on the search for identifying patterns of how to teach well - to detect what teachers do, or could do, efficiently that leads to student success; in this case, it means detecting what students are able to reproduce about the knowledge transmitted, which can be verified through their performance.

The second element that, in our view, contributes to building a notion of teaching, based on J's account, is how she addresses the textbook. She complains, while talking about the difficulties and how she got lost on the first day of teaching, that in the public school "there wasn't even a textbook." Of course, a textbook can be useful to help teachers know what content was addressed in previous levels. In language teaching, however, textbooks generally do more than that - they are regarded many times as the very course content, syllabus, method, and even curriculum (TILIO, 2006; 2010).

Kumaravadivelu (2012:21) highlights the relationship of language teaching and textbooks as one of dependency: teachers and learners become dependent on textbooks produced in centre-based countries, whose industries profit from the millions of copies sold every year. According to him, those textbooks are usually full of "trivial and biased cultural content" (KUMARAVADIVELU, 2012:23). Ferreira and Brigolla (2013) and Block (2017) affirm that textbooks do not reflect, though they should, the realities that teachers and students share in their local classroom. All of this together reinforces our understanding here that textbooks are, in many cases, synonymous with a certain view of teaching, that is, they tell teachers what has to be taught and how, and teaching easily comes down to knowledge transmission. This remains a sign of coloniality in the sense that others (book writers, specialists, for instance) prescribe what to teach as if they supposedly knew more 
about us teachers, about our students, our schools, our wants, and our realities than we ourselves do.

As we said before, in our inquiry we have found it intriguing that Luciano Ricardo presented such different views of his education and professors, the school, students, language, and of himself as a teacher. In order to question possible reasons for it, we showed him some slides with a list of excerpts with his own views and asked why he thought he had such opinions. When talking about the kind of education he was offered at the university in order to become a teacher, he said:

I think that the university gave me opportunity, opportunity to read, to understand. Most of my teachers never said: "do this, do that"; most of them always showed me opportunities, methodologies, and possibilities. I think in that sense the teacher education course prepared me, but it is an unprepared preparation. [...] I do not know what I'm going to face, but I have courage, you know? "Let's do it," but I know I'll have to stop and go to the sources, read again, study again.

Differently from J, Luciano Ricardo presented contrasting views on teaching. Interesting to notice is that he uses words in the plural when referring to his teacher education course: "opportunities, methodologies, and possibilities." Instead of referring to "a method," as J did, he mentions that he was shown "methodologies." This strikes us that teaching is not one set of fixed pre-given procedures to be followed so that knowledge can be transmitted and learning can take place. Teaching, then, becomes rather open, a matter of possibilities, therefore depending on contexts and subjects. Maybe this is why he does not refer to his teaching experience as a chaos in which he got lost and did not know what to do due to lack of preparation.

In order to go against colonial teacher education, Jordão and Bührer (2013:682) talk about the importance of student teachers gaining "agency, constructed in the discursive process, in the ambivalent and contingent moments and spaces that characterise teacher education as a whole and teachers' professionalization in particular." We understand, from Luciano Ricardo's excerpt, that he undertakes agency when he talks about methodologies and possibilities instead of being told "do this, do that." By seeing them in the plural, not as fixed or singular, he 
seems to understand that he can make decisions rather than simply obey external, pre-established rules in the process of language teaching.

All of this seems to help him feel more ready for teaching ("have courage," as he says), differently than J's view of herself. Also, as can be understood from his affirmation in "the teacher education course prepared me, but it is an unprepared preparation," Luciano Ricardo does not see teaching as possible to be learned once and for all in the four-year course at the university in Brazil. He seems to have learned how to "let go of the investments and desires for failure-proof predetermined scripts (e.g. perfect frameworks, failure-proof lesson plans and teleological modes of thinking about the future) and open up more responsive and exciting possibilities in education" (ANDREOTTI, 2013:i). As Lopes and Borges (2015) claim, teacher education is an impossible but necessary project. Teaching is open to possibilities, contingent, and context-dependent; therefore, he can start teaching once he is licensed, because he is ready to "talk" (SKLIAR, 2006) to the school community, as he puts it in: "I know I'll have to stop and go to the sources, read again, study again."

Before graduating in English Language Teaching (Letras: Inglês), Luciano Ricardo first graduated as a Portuguese teacher (in Letras: Português) from the same university. He compared how both courses dealt with teaching:

I felt that in the English Teacher Education Course the issues of foreign language teaching and literacy arose only in disciplines such as Teaching Methodology and English Practicum. When you are doing courses such as oral comprehension, written expression in English, these issues do not exist. The word teaching (licenciatura) does not exist in any English literature discipline you take, for example. Teaching (licenciatura), it does not exist. Only in the Teaching Methodology and Practicum Courses. And in the Portuguese Teacher Education Course, no. I feel that the pedagogical perspective, of teaching, is there right from the beginning. I think so.

His words above highlight the importance of a teaching perspective throughout all the years of teacher education courses in Brazil. He hits on the fact that some disciplines in the English field do not consider that student teachers are there to learn how to teach right from the beginning; disciplines that have a focus on the English language itself 
many times do not take into account that the teaching and learning, the translanguaging (more on this later), and all social practices taking place there are rich processes to be brought into focus, discussed, shared, and made objects of inquiry.

In this sense, Castro (2008) argues that in language teacher education courses that keep language disciplines (such as English Oral Comprehension etc.) and pedagogical disciplines (such as Foreign Language Teaching Methodology etc.) apart, as if they were two separable fields, teaching is held as information transmission to be acquired by students. She continues by saying that this is the predominant model in Brazil, hardly preparing teachers to face the "multiple and complex teaching-learning situations that are part of classroom realities" (CASTRO, 2008:309).

Teacher educators too often tend to lose sight of how teaching is being exercised across the very curriculum in effect and that student teachers learn to teach from the very instruction and lessons they receive throughout their university life (REIS et al, 2008; BASSO, 2001; ALVARENGA, 1999). Therefore, it is not redundant to state that language teacher education should home in on language teaching: considering it here as "new terrains" and "epistemic travel," as Domínguez (2017:226) claims against simply reproducing colonial, Eurocentric models of teaching. We agree with Biesta (2012b) in that we should bring teaching back into focus in teacher education and examine the meanings of teaching entrenched in the university praxes.

\section{Teachers' views of the subject and what happens when we get there to teach}

As we have been discussing so far, we believe the way teachers conceive of elements such as teaching, the subject, and language seems to be fundamentally implicated in how they feel, react, and make sense of their encounters with the school when it is time to start teaching. In this section, where we aim at discussing notions of the subject and identity (used here interchangeably), we align with Kumaravadivelu (2012) in that matters of identity must be addressed in order to move away from center-oriented language teaching and learning. For the 
purposes of our discussion here, this means questioning not only fixed ways of understanding who teachers, students, and other people from the whole school community are, but also fixed roles they are expected to have and play for things to work out fine in that context.

Donny, another student teacher participating in our research, narrated his teaching experience in a public school as follows:

Donny: At first the experience was a little... I wouldn't say it was traumatizing, but it was a little bit... I didn't know what to expect. And, although I didn't expect much, it was surprising. The type of students, uhh... the type of students, the amount of students per class, uhh... the organization of the school, I didn't know the space of the school, didn't know how it worked. [...] I found the school unprepared, people who seemed to be a little lost, and... maybe just doing what they always used to do, people who didn't stop much to think over what they were doing, they just kept doing what they were used to. And... I don't know, I expected the students to be more disciplined.

We get intrigued by the fact that everything he narrates to describe his teaching practice is under the term "traumatizing" - the encounter with the students, the school organization, and all the "people" there. Although he said he "didn't expect much," his evaluation of everything and everyone seems to show he did have expectations of how things were supposed to be. To start with, he mentions the "type of students and the amount of students per class," meaning that maybe something was not totally corresponding or, at least, it was going against his expectations. Later on, he says he "expected the students to be more disciplined." All of this together seems to point out he had clear-cut ideas of what students are and how they should behave, which his experience did not conform to. What kind of students do we expect to meet at school, after all? What makes experiences "traumatizing" in the encounter with the school when we should get to know and teach students? What kind of discourses or "truths" are produced and reproduced in teacher education about whom school people are?

Lima and Sales (2007) discuss that negative, biased representations of public school students learning English in Brazil are many times endorsed by school teachers and reproduced in teacher education: school students are referred to as living in low socioeconomic situations, 
lacking pedagogical resources both at home and at school, having cultural and cognitive deficit, despised by the government, and studying with uncommitted teachers and school staff. The authors discuss that these biased views usually structure "being and doing" (LIMA; SALES, 2007:119, emphasis in original) in a pessimistic tone towards public school students.

In view of such representations, we ask: where do such concepts come from? From many different social fields, one could answer; however, they all stem from discursive truths of how "normal" students are supposed to be in schools. These discourses dictate the norm - the fixed, normative identity. According to Woodward (2000), normal identities are historically and socially constructed patterns of how certain people are and, therefore, should always be expected to be. She adds that these patterns are formed in unequal power relations in society, through legitimate and socially recognized knowledge. Hall (2003:4) also points out that

\begin{abstract}
[p]recisely because identities are constructed within, not outside, discourse, we need to understand them as produced in specific historical and institutional sites within specific discursive formations and practices, by specific enunciative strategies. Moreover, they emerge within the play of specific modalities of power, and thus are more the product of the marking of difference and exclusion, than they are the sign of an identical, naturallyconstituted unity.
\end{abstract}

The same author also underlines that identity is constructed through, not outside, difference, which brings along the "disturbing recognition" (HALL, 2003:4) that

it is only through the relation to the Other, the relation to what it is not, to precisely what it lacks, $[\ldots]$ that the "positive" meaning of any term - and thus its "identity" - can be constructed (HALL, 2003:4, emphasis in original).

Identity, then, is always in close and inseparable relationship with difference. When we categorize a student with any affirmation, for example, such affirmation is only possible because of our wish to mark her or his identity out of the innumerous possibilities of being and becoming around us. To Silva (2000), difference, rather than identity, 
is what really exists; this means that categorizations, classifications, groupings, rankings etc., are ways power uses to operate distinctions and mark identities, which, otherwise, would not naturally subsist in or by themselves.

Considering the relationship between identity and difference, we underscore the fact that the social representations of public school students learning English, as presented above, are constructed through idealized standards of how people, in order to really learn a language, have to be; those who do not fit in are regarded as hopeless, lacking the necessary skills to achieve learning, as Lima and Sales (2007) show. Damascena and Mastrella-de-Andrade (2017) discuss that student teachers, before encountering the school as a professional field, have images of public school students as disrespectful, careless, and unwilling to learn English. However, they argue that, after experiencing the school life (by teaching and building relationships with the students) for one or two semesters, many of them reexamined, challenged, and even transformed those stereotypical views, gaining a renewed understanding of the school as an open, unfixed, and unfixable place.

What seems to have happened to Donny, though, is not exactly that, as we could see in his narrative excerpt transcribed above. He ended his teaching experience during the English Practicum with a very negative view of the school as a whole. His initial, fixed expectations of how classrooms, students, and school organization should be were maybe too strong to be defied in his encounter with the school and, besides that, he did not have a more flexible and resilient view of how people in the educational settings are in order to have a more relational, open experience with them.

With that in mind, we underline the need to discuss identity in language teacher education and the understandings we have about who the subjects are. In that sense, are we (the ones who teach and are taught) rationally knowable people that we (the ones who teach and are taught) study, grasp, and get to know well beforehand in order to prepare to teach, or are we subjects whose identities are contextually and contingently constructed and, precisely because of that, must engage in social practices and relationships in order to understand what types of learning and teaching are best needed and wanted? 
Differing somewhat strikingly are the lived practices of student teacher Luciano Ricardo (LR):

Interviewer ${ }^{5}$ : Do you think the university has prepared you to face problems $[\ldots]$ ?

Luciano Ricardo: I think the success I have had in teaching English is due to the things I have learned at the university. I frequently say "today I'm going to assess my students this way because one day a professor discussed this with me or assessed me that way." In that sense the teacher education course did prepare me, but it is an unprepared preparation, it is the preparation of the subject, you know? And I think at school it's like this... When you're teaching there, you teach the same thing to all the students but it ends up differently... because it's the human condition of missing... But I think what must be instigated is the search, students should be instigated to search, and I think the university prepared me to search.

In his words above, we notice Luciano Ricardo regarded the university and the teacher education course he took part in as the place where he learned a lot about teaching. Differently from Donny's, his understanding of what teacher education or preparation is stems from open notions of the subject, which also influence all his view of a public school community.

Interesting to notice is that he makes mention of his teacher education as "unprepared preparation." This refers us to the question Lopes and Borges (2015) discuss so deeply: how can it be possible to say we prepare or educate teachers once and for all? The authors regard it as an impossible, though necessary, project; for them, prediction and calculation in teacher education is impossible, but it does not mean it is not necessary. It is necessary because "we are called to give meaning to the world, because we are mobilized by the quest to stabilize the chaos of existence, to find points of approximation" (LOPES; BORGES, 2015:499).

All this has to do with the end of the project of teacher education in a fixed way; Lopes and Borges (2015) advocate, as we do, too, giving up on a teacher education project that sees the school (teachers, students, the whole community) as a knowable place with knowable subjects

5. The interview was carried out by undergraduate students under the supervision of the first author of this article. 
that we grasp beforehand and, when we get there, strive to conform to the rationalities we bring along. As a result, scholars (JORDÃO, 2008; CAMPANI, 2006) show that frustration, disheartening, disappointment, sense of powerlessness, and a strong will to give up on the career seem to usually follow those approaching the school in these rather rational, fixed models of teacher education, as we can see in J's and Donny's accounts here.

Instead of giving them all the answers in order to feel prepared, the university and teacher education courses, as Luciano puts it, should prepare teachers to be open "to search," since new and complex contexts and questions constantly arise and answers will vary; since students and teachers come from different contexts, with different stories, realities, and desires - therefore, identities. Lack of certainties, instead of demobilizing, "is our antidote against authoritarianism and can be the lever for different forms of mobilization" (LOPES; BORGES, 2015:503).

Luciano Ricardo mentions his contact with psychoanalytic theories in his teacher education course, especially concepts on "the subject of missing" or "the subject of lack," as a basis for understanding subjects as incomplete and always heterogeneous. Interesting to notice is how he accepts dialectically that being ready to teach does not imply knowing all about it, but, at the same time, implies a kind of preparation that is responsible and focused on "searching." That, to our minds, does not mean giving up on language learning/teaching knowledges or taking teacher education less seriously. It involves, on the contrary, understanding such knowledges as situated and incomplete (PATEL, 2015), considering that local places must have a say in their teaching and learning processes as equally valid knowledge. This refers to the concept of ecology of knowledges (SOUSA SANTOS, 2007), which constitutes an important component for teacher education: it rejects the modern science monoculture and its perspective that universalizes what Grosfoguel (2008:140) calls the euro-usa world-system. An ecology of knowledges "enables us to have a much broader vision of what we do not know, as well as of what we do know, and also to be aware that what we do not know is our own ignorance, not a general ignorance" (SOUSA SANTOS, 2007:94). In this sense, preparing teachers "to search," as Luciano Ricardo pointed out, becomes central to considering 
that, if our ignorance may be answered locally (not only by center-based theories), local places other than the university do have knowledges that count and must be recognized as such.

When asked if his comprehension that we are all different, fragmented, incomplete, and socially constructed subjects is important in teacher education, Luciano Ricardo declared:

I think so. [...]. I think maybe a big problem we have is not to be able to accept ourselves as incomplete, not to be able to accept ourselves imperfect. In the case of language, for example, I parallel it this way: if you think you can only speak or write a language on the day you know it all, you'll never speak it.

We found his parallel between subject and language important and meaningful to be considered. The way language is conceived, then, is discussed in the next section as a third fundamental element to make a difference in language teacher education and in teachers' encounters with the school.

\section{A view of language, a view of (im)possibilities}

Considering the ways student teachers reported their English teaching experience at public schools as chaotic, fearsome and disheartening, we found it important to discuss their understandings of language, bearing in mind that they are influential over the way we feel, act, and react in language teaching. As we have been discussing thus far, the way we conceive teaching, the subject/identity, and language can make a difference when teaching. When it comes to language, as is the aim in this section, we take Luciano Ricardo's words in the following excerpt very seriously, as he says:

The English teacher education course looks rather technical. I think student teachers expect to have a technical education [...]. This thing of wanting to have a textbook, a method, it seems like in English teacher education we get only the hard core of language and feel like leaving all the rest of language out. 
The term technical to refer to English teacher education in Brazil deserves, in our opinion, to be explored. The "technical" part would be language structure - grammar and structural aspects that are usually valued in language teaching mainstream thought; "the rest," we could only wonder to be discourse and other sociocultural aspects, is left out, as they are minor realities in language teaching or teacher education. However, according to Jordão (2008:7), emphasis in “"purely' linguistic objectives" has generated frustration in teaching and learning English in Brazil, since it regards learning solely on the basis of the mechanical acquisition of linguistic structures, such as grammar and vocabulary, without any care to the relevance of historical, sociocultural, and power discourses that sustain and embody every language practice (FOUCAULT, 1979) in our daily lives.

Nevertheless, new and vigorous praxes have emerged in Brazil in resistance to this more "technical" side of English teacher education, as we can infer from Luciano Ricardo's words. What mainstream thought (as we could see in Luciano Ricardo's words) calls "the rest" out of language is precisely what critical praxes place as of great importance for all of us using, learning, living, making ourselves through languages: we learn by reading (in the Freirean sense) the many discourses texts (in their many different forms each day) produce, reproduce, and transform. By learning to see language not only as structure or simply as a tool for communication, but rather as what constitutes us (BAKHTIN, 1988) in social life and what is constantly constructing meanings in society, we learn to use it, and, what's more, it makes a difference in the way we understand our relationship with the world, as Weedon (1997) and Jordão (2007) put it.

In this sense, we underscore the need that language teacher education keeps on revisiting its concepts of language. Language itself is a construct that must be called into question. Makoni and Pennycook (2007), as well as García and Wei (2014), cast doubt on the very concept of any language as we commonly know them as a closed system that someone (in this case, "the native") would master: Portuguese, English, French, Spanish (to name just the ones that were instruments of colonization) as separate, individual, well-defined languages are a colonial invention in order to name and limit the colonized. What they 
say exists, based on what people do in reality, is a flow of repertories people possess and negotiate in order to use, create meanings, and make sense of the world. Their view emphasizes "the agency of speakers in an ongoing process of interactive meaning-making" (GARCÍA; WEI, 2014:9).

These authors follow Blommaert's (2010) idea of a sociolinguistics of globalization, according to which languages are mobile resources or practices in dynamic cultural, social, historical, and political contexts. In this sense, language is seen as a practice - local practice: what we do rather than a system we resort to; material part of social and cultural life rather than an abstract entity; an activity rather than a structure (PENNYCOOK, 2010). This has enormous consequences to teaching and learning languages as well as to language teacher education. As Canagarajah (2007:233) puts it,

once we acknowledge that languages are inherently hybrid, grammars are emergent and communication is fluid, we are left with the problem of redefining some of the most basic constructs that have dominated the field of linguistics.

Language and language teaching being some of them. This refers us back to Luciano Ricardo's accounts of his teacher education experience. Since he referenced English teacher education as very "technical," that is, pretty much focused on language as structure, rather than language as discourse or repertories we use and negotiate, create, and make sense of meaning, he points out that, as a consequence,

this very technical English teacher education tells you more like this: "look, you have a very interesting opinion, you've made a great interpretation of that book you read, but you don't speak like a native, so you'd better not speak." I don't speak English that good, but I don't keep quiet in class [...]. It hurts my ego somehow, but it does not hurt it to death.

What we see in his words above is a vehement sample of the longheld, naturalized, and still vivid belief that how we say things (must!) matter more than what we say (MASTRELLA-DE-ANDRADE, 2011; PESSOA; URZÊDA-FREITAS, 2016; PESSOA; HOELZLE, 2017; PESSOA; BORELLI; SILVESTRE, 2018). Language here is understood 
as a totalising system that has to be acquired as a whole in order to be considered perfect. Perfection, in this case, has a representative: the native speaker, whose language is supposedly pure and free from influences; that is why Luciano Ricardo points out that "if you don't speak like a native, you'd better not speak." This is what García and Wei (2014) call a colonialist, monolingual perspective on language and language teaching: it denies that all languages are in interaction and speakers resort to them all for different reasons and needs; they argue that in reality languages are never pure or influence-free, but rather interconnected. These authors understand that individuals do not possess separate competences for using different languages; therefore, thinking of languages as separate, autonomous systems does not help explain what speakers do in their local realities.

Lucena (2015:68) highlights that "the multimodal, plurilingual reality that represents the decline of monolingual life is set, even if sectors of the society resist to think of it as such." Considering, then, as the same author affirms, that language classroom is deeply plurilingual and transcultural, and that speakers can establish effective communication using different linguistic and semiotic resources, rethinking our concepts of language from monolingual perspectives to a more fluid one has to do with "assuming a democratic logic in which interlocutors, when in egalitarian conditions, may flow freely through language heterogeneity" (LUCENA, 2015:76). This means giving up on the reproduction of unjust and colonialist views that there is such a thing as a "native speaker" or the idealisation of whatever his or her language is.

All this is especially important for language teacher education in Brazil, in our view, for two reasons, which we would like to explore a little further here in order to draw this article to an end. Firstly, a more fluid and heterogeneous view on language is important especially because our schools, whether public or private, are inhabited by students coming from different realities, with different socioeconomic, linguistic, and semiotic resources. Requiring them to have resources of only one kind - from a monolingual, totalised/totalising, and idealised language perspective - serves only and primarily to silence and place them as unteachable or helpless, hopeless learners, perpetuating the 
colonial epistemology from center-based countries (FERREIRA, 2018; KUMARAVADIVELU, 2012). Let's take here what Sousa (2009) argues about schools in Brazil: they are mostly willing and prepared to teach those who already have school-like discipline, culture, and sociability. This, to our minds, encompasses language in all senses: if the students' language is not as expected by the schools' monolingual standards, they are doomed to fail, for their communication resources are not considered as legitimate. It is precisely because of this reality that we insist on revising our concepts of language in language teacher education in Brazil. It is about time we learned to see our classrooms as multilingual places where students' different repertoires can be used as resources for learning.

Connected to this is the second point we would like to discuss here in favour of reviewing our concepts of language to a more fluid one in language teaching and teacher education. If language is what constitutes us (WEEDON, 1997; BAKHTIN, 1988), then language classrooms must emphasize the what, not the how, we speak. Critical literacy perspectives have taken this very seriously, understanding language not as structure to be acquired, but rather as a social practice (FERREIRA, 2018; JORDÃO, 2007; MENEZES DE SOUSA, 2011; PENNYCOOK, 2010; PESSOA; HOEZLE, 2017; PESSOA; BORELLI; SILVESTRE, 2018). For these perspectives, it is in and through language that discourses construct identities, truths, realities; therefore, they matter immensely in language teacher education and in language classrooms. It is by giving up on language lessons based on mere "neutral" structure in order to focus on topics, texts, audios, visuals, or whatever semiotic material that really matters to students' lives that new methodologies can be possibly created and developed in and for the interest of periphery countries (KUMARAVADIVELU, 2012). More than resistance, it may be characterized as re-existence (WALSH; MIGNOLO, 2018) in language teacher education. The term re-existence is used by these decolonial authors and is described as the "resurgence and insurgence of re-existence today that open and engage venues and paths of decolonial conviviality, venues and paths that take us beyond, while at the same time undoing, the singularity and linearity of the West" (WALSH; MIGNOLO, 2018:3). 


\section{Final thoughts}

In this study, we aimed at problematizing discourses about the "unpreparedness to teach languages at schools," recurrent in language teacher education in Brazil. Our inspiration was Luciano Ricardo, a student teacher at the Universidade de Brasilia, whose accounts radically diverge from the current discourses in the area and touch three crucial aspects, which are teaching, the subject and language. In our discussion, we have confronted his accounts to other student teachers' and to scholars' from the fields of applied linguistics, poststructuralism and decolonial thinking.

Our discussion suggests that it is about time teacher education courses in Brazil challenged modernist conceptions of teaching, the subject, and language. In fact, teaching is far from being a matter of having a method or a textbook; rather, it is a matter of possibilities created by the agents who take part in each context and know how "to talk" (SKLIAR, 2006: 32). Besides, as the subject is not fixed or rational, school agents cannot be known in advance if they can be known at all; our subjectivities arise from the interaction we have with others. Openness to meet and get to know them in the encounters with the school is a must, then. Finally, language is not only a language system, but also fluid repertoires that constitute us and that people make use of to make sense of the world and to build it.

Grounded on poststructuralist and decolonial perspectives of these three elements involved in education, we can only think of teacher education as an impossible project (LOPES; BORGES, 2015) if we think of teaching and learning as a cause and effect process and if we take results for granted; impossible, but necessary, as the authors point out, since this is our doing and our bet to build a different, more hopeful world. We see this movement of preparing for the unexpected in teacher education as decolonial, since teachers start administering not specific fractions of knowledge, but rather productive spaces for its construction (PATEL, 2015) and for the development of an ethic that should guide us both in our practice of socialization and in our criticism of it (PENNYCOOK, 2001). 


\section{References}

ALVARENGA, Magali B. 1999. Configuração de competências de um professor de língua estrangeira (inglês): implicações para a formação em serviço, 1999. 301f. Tese (Doutorado em Linguística Aplicada) Universidade Estadual de Campinas, Campinas.

ASSIS-PETERSON, Ana Antônia; SILVA, Eladyr M. N. da. 2011. Os primeiros anos de uma professora de inglês na escola pública: tarefa nada fácil. Linguagem \& Ensino, 14(2):357-394.

BAKHTIN, Mikhail. 1988. Marxismo e filosofia da linguagem. São Paulo: Hucitec.

BASSO, Edcleia A. 2001. A construção social das competências necessárias ao professor de língua estrangeira: entre o real e o ideal: um curso de Letras em estudo, 2001. 336f. Tese (Doutorado em Linguística Aplicada) - Universidade Estadual de Campinas, Campinas.

BIESTA, Gert. 2012a. The future of teacher education: evidence, competence or wisdom? RoSE - Research on Steiner Education, $3(1): 8-21$.

BIESTA, Gert. 2012b. Giving teaching back to education: responding to the disappearance of the teacher. Phenomenology \& Practice, 6(2): 35-49.

BLOCK, David. 2017. Neoliberalism, the neoliberal citizen and English language teaching materials: a critical analysis/Neoliberalismo, el ciudadano neoliberal y los materiales para la enseñanza de la lenagua inglesa: un análisis crítico. Ruta Maestra, 21:4-15.

BLOMMAERT, Jan. 2010. The sociolinguistics of globalization. Cambridge: Cambridge University Press.

BORELLI, Julma D. V. P. 2018. O estágio e o desafio decolonial: (des) construindo sentidos sobre a formação de professores/as de ingles, 2018. 223f. Tese (Doutorado em Letras e Linguística) - Universidade Federal de Goiás, Goiânia.

CAMPANI, Daiana. 2006. Reflexões sobre ensino de línguas materna e estrangeira no Brasil: aproximações, distanciamentos e contradições. Linguagem \& Ensino, 9(2): 201-221.

CANAGARAJAH, Suresh. 2007. After disinvention: possibilities for communication, community and competence. In: MAKONI, Sinfree; PENNYCOOK, Alastair. (Ed.). Disinventing and reconstituting languages. Clevedon: Multilingual Matters: p. 233-239.

CASTRO, Solange T. R. 2008. Formação da competência do futuro professor de inglês. In: LEFFA, Vilson. (Org.). O professor de línguas 
estrangeiras: construindo a profissão. 2. ed. Pelotas: EDUCAT: 307322.

CELANI, Maria Antonieta A. 2003. Um programa de formação contínua. In: CELANI, Maria Antonieta A. (Org.). Professores e formadores em mudança: relato de um processo de reflexão e transformação da prática docente. Campinas: Mercado de Letras: 19-35.

DAMACENA, Mariana M. R.; MASTRELLA-DE-ANDRADE, Mariana R. 2017. A construção da identidade de alunos/as da escola pública nos discursos de licenciandos/as em Letras Inglês. Anais do $23^{\circ}$ Congresso de Iniciação Científica da Universidade de Brasília e 140 do Distrito Federal.

DOMÍNGUEZ, Michael. 2017. "Se hace puentes al andar": Decolonial Teacher Education as a needed bridge to culturally sustaining and revitalizing pedagogies. In: PARIS, Django; ALIM, H. Samy. Culturally sustaining pedagogies: teaching and learning for justice in a changing world. New York: Teachers College Press: 225-246.

FERREIRA, Aparecida. J.; BRIGOLlA, Fernanda C. 2013. A representação de gêneros em livros didáticos de língua inglesa. Revista Uniabeu, 6(14): 1-19.

FERREIRA, Fernanda C. da C. 2018. Problematizando sentidos de língua em uma sala de aula de língua inglesa. 2018. 159f. Dissertação (Mestrado em Letras e Linguística) - Universidade Federal de Goiás, Goiânia.

FOUCAULT, Michel. 1979. Microfisica do poder. 1. ed. Rio de Janeiro: Graal.

GARCÍA, Ofelia; WEI, Li. 2014. Translanguaging: language, bilingualism and education. New York: Palgrave Macmillan.

GROSFOGUEL, Ramón. 2008. Para descolonizar os estudos de economia política e os estudos pós-coloniais: transmodernidade, pensamento de fronteira e colonialidade global. Revista Crítica de Ciências Sociais, 80: $115-147$.

HALL, Stuart. 2003. Who needs identity? In: HALL, S.; DU GAY, Paul. Questions of cultural identity. London: Sage Publications: 1-17.

JORDÃO, Clarissa M. 2008. A postcolonial framework for Brazilian EFL teachers' social identities. Revista Matices, Universidad Nacional de Colombia, Diciembre 2008. Disponível em: <https://revistas.unal. edu.co/index.php/male/issue/view/1239/showToc $>$. Acesso em: 12 jul. 2018.

JORDÃO, Clarissa M.; BUHRER, Édina A. C. 2013. A condição de aluno-professor de língua inglesa em discussão: estágio, identidade e agência. Educação e Realidade, 38(2): 669-682. 
JORDÃO, Clarissa M. 2007. As lentes do discurso: letramento e criticidade no mundo digital. Trabalhos em Linguística Aplicada, Campinas, 46(1): 19-29.

KADER, Cárla C. C.; RICHTER, 2012. Marcos Gustavo. Formação e identidade do professor de línguas: uma análise sociodiscursiva de narrativas. Anais do SIELP, 2(1). Uberlândia: EDUFU: 1-11.

KUMARAVADIVELU, Bala. 2012. Individual identity, cultural globalization and teaching English as an international language: the case for an epistemic break. In: ALSAGOFF, Lubna; RENANDYA, Willy A.; HU, Guangwei; MCKAY, Lee S. (Ed.). Teaching English as an international language: principles and practices, New York: Routledge: 9-27.

KUMARAVADIVELU, Bala. 2014. The decolonial option in English language teaching: can the subaltern act? TESOL Quarterly, 50(1): 66-85.

LIMA, Francisca de F. de; SALES, Luís Carlos. 2007. As representações sociais do aluno de escola pública partilhadas por professores de língua inglesa que ensinam em escolas públicas e particulares de Teresina. Atos de Pesquisa em Educação, 2(1): 106-122.

LOPES, Alice C.; BORGES, Veronica. 2015. Formação docente, um projeto impossível. Caderno de Pesquisa, 45(157): 486-507.

LOPES, Carlos Renato. 2013. Repensando os saberes: mudanças nos paradigmas epistemológicos e a formação de professores de língua estrangeira. Revista Brasileira de Linguística Aplicada, 13(3): 941962.

LUCENA, Maria Inês P. 2015. Práticas de linguagem na realidade da sala de aula: contribuições da pesquisa de cunho etnográfico em Linguística Aplicada. D.E.L.T.A., (31): 67-95.

MAKONI, Sinfree; PENNYCOOK, Alastair. 2007. Disinventing and reconstituting languages. Clevedon, Buffalo, Toronto: Multilingual Matters.

MASTRELLA-DE-ANDRADE, Mariana R. 2011. Quem aprende e onde se ensina inglês? Desafios do ensino da competência linguísticocomunicativa na formação docente. SIGNUM: Estudos da Linguagem, 14(1): 345-362.

MENEZES DE SOUZA, Lynn Mario T. 2011. Para uma redefinição de letramento crítico: conflito e produção de significação. In: MACIEL, Ruberval F.; ARAUJO, Vanessa de A. (Org.). Formação de professores de línguas: ampliando perspectivas. Jundiaí: Paco editorial: 128-140. 
MIGNOLO, Walter D.; WALSH, Catherine E. 2018. Introduction. In: MIGNOLO, Walter D.; WALSH, Catherine E. (Ed.). On decoloniality: concepts, analytics, praxis. Durham: Duke University Press: $1-12$.

PATEL, Leigh. 2015. Education research as a site of coloniality. In: PATEL, Leigh. Decolonizing educational research: from ownership to answerability. New York: Routledge: 11-27.

PENNYCOOK, Alastair. 2001. Critical applied linguistics: a critical introduction. Mahwah, NJ: Lawrence Erlbaum.

PENNYCOOK, Alastair. 2010. Language as a local practice. London and New York: Routledge.

PERRENOUD, Philippe. 1999. Formar professores em contextos sociais em mudança. Prática reflexiva e reflexão crítica. Revista Brasileira de Educação. 12:5-19.

PESSOA, Rosane R., ANDRADE, Maria Eugênia S. F. de; FERREIRA, Edilson P. 2017. A critical teacher education experience in the state of Goiás, Brazil. Revista Brasileira de Linguística Aplicada, 18(2): 339-366.

PESSOA, Rosane R., BORELLI, Julma D. V. P.; SILVESTRE, Viviane P. V. 2018. Speaking properly: language conceptions problematized in English lessons of a university teacher education course. Ilha do Desterro, 71(3): 81-98.

PESSOA, Rosane R.; HOELZLE, Maria José L. R. 2017. Ensino de línguas como palco de política linguística: mobilização de repertórios sobre gênero. Trabalhos em Linguística Aplicada, 56(3): 781-800.

PESSOA, Rosane R.; URZÊDA-FREITAS, Marco Túlio. 2016. Língua como espaço de poder: uma pesquisa de sala de aula na perspectiva crítica. Revista Brasileira de Linguística Aplicada. Belo Horizonte, 16(1):133-156.

REIS, Simone; GIMENEZ, Telma; ORTENZI, Denise I. B. G.; MATEUS, Elaine. 2008. Conhecimentos em contato na formação pré-serviço. In: LEFFA, Vilson. (Org.). O professor de línguas estrangeiras: construindo a profissão. 2. ed. Pelotas: EDUCAT: 261-276.

SCHWANDT, Thomas. A. 2006. Três posturas epistemológicas para a investigação qualitativa. In: DENZIN, Norman. K.; LINCOLN, Yvonne. S. (Org.). O planejamento da pesquisa qualitativa: teorias e abordagens. Porto Alegre: Artmed: $193-217$.

SILVA, Tomaz. T. 2000. A produção social da identidade e da diferença. In: SILVA, Tomaz Tadeu da (Org.). Identidade e diferença: a perspectiva dos estudos culturais. Petrópolis: Vozes:73-102. 
SKLIAR, Carlos. 2006. A inclusão que é nossa e a diferença que é do outro. In: RODRIGUES, David. (Org.). Inclusão e educação: doze olhares sobre a educação inclusiva. Summus Editorial: 15-34.

SOUSA, Jessé. 2009. A ralé brasileira: quem é e como vive. Belo Horizonte: Editora da UFMG, 2009.

SOUZA SANTOS, Boaventura de. 2007. Para além do pensamento abissal: das linhas globais a uma ecologia de saberes. Novos Estudos CEBRAP, 79: 71-94.

TÍLIO, Rogério C. 2006. O livro didático de inglês em uma abordagem sócio-discursiva: culturas, identidades e pós-modernidade. Rio de Janeiro: Pontifícia Universidade Católica, 2006. 258f. Tese (Doutorado em Letras) - Pontifícia Universidade Católica do Rio de Janeiro, Rio de Janeiro.

TÍLIO, Rogério C. 2010. A representação do mundo no livro didático de inglês como língua estrangeira: uma abordagem sócio-discursiva. The Especialist, 31: 167-192.

WEEDON, Chris. 1997. Feminist practice and poststructuralist theory. 2. ed. London: Basil Blackwell.

WOODWARD, Kathryn. 2000. Identidade e diferença: uma introdução teórica e conceitual. In: SILVA, Tomaz T. da. (Org.). Identidade e diferença: a perspectiva dos estudos culturais. Petrópolis: Vozes: 7-72. 